\title{
樺太植民地農政の中の近代天皇制 樺太篤農家事業と昭和の大礼の関係を中心にして—
}

\author{
The Modern Imperial Institution of Japan for the Colonial Agricultural \\ Administration of Karafuto: The Relationship between the Exemplary Farmer \\ Campaign of Karafuto and the Ceremony of the Showa Emperor
}

\author{
中山 大将* \\ Taisho NAKAYAMA
}

The imperial Constitution of Japan was established in 1889 and this meant that the modern Japanese imperial institution was also established. The imperial institution in this updated form remained influential throughout the Japanese Empire.

In 1928, the Showa Emperor succeeded to the throne and a series of the ceremonies were held to recognize the transition called "Showa-no-Tairei." Concurrently, in the imperial colony of "Karafuto," the exemplary farmer campaign was launched by the colonial government of Karafuto.

First, this study clarifies the facts on how the colonial agricultural administration of Karafuto utilized the modern imperial institution through the exemplary farmer campaign for its own particular aims. Second, this study discusses the logic for the linkage between Karafuto farmers and the Emperor within the campaign.

The colonial government needed to use imperial ideology to make farmers of Karafuto adopt the ideal farming style it had planned, which differed from that of mainland Japan. The colonial government exposed the farmers to Imperial linkages via the ceremony of "Showa-no-Tairei," in which the farmers were honored, and attempted to legitimize these linkages through the campaign.

The logic behind these steps depended on three facts. First, the Showa Emperor toured Karafuto and granted an audience with some of the exemplary farmers when he was the prince. Second, he planted rice on a paddy field in the palace after the demise the Taisho Emperor. Third he made honorable recognition of some of the farmers and used and ate crops dedicated by the farmers at the ceremony of accession, "Showa-no-Tairei." The colonial government hoped that the farmers and agriculture of Karafuto would become linked with the Emperor and the Empire itself by these facts, and that this linkage would familiarize farmers with an ideology of hard work in order to attain the farming style planned by the colonial government.

\section{1. 課題と方法}

大日本帝国憲法が発布され皇室典範も定まった 1889 年以降、近代日本は「立憲君主制国家」として の道をたどることとなる。現実の政治の流れが欽定 憲法制定を経ての議会開設となったことを踏まえれ ば、近代天皇制が確固たるものとして定置されたの もこの時期とみなすことは可能であろう。事実、そ の後、この欽定憲法に関して、より民主度の高い解 䣋や運用をめぐる議論や運動が起きたのであり、そ こでの争点はしばしば「天皇」という語が刻まれた 憲法の各条項であったというのが、坂野潤治（2008） の論ずるところである。

*京都大学大学院
安丸良夫は、既存の天皇制研究を「連続説」「断絶 説」に分け、自身を後者に入れ、「古い伝統の名にお いて国民的アイデンティティを構成し国民国家とし ての統合を実現することは、近代国民国家の重要な 特質のひとつであり、そうしたいわば偽造された構 築物として、近代天皇制を対象化して解析する」こ とを課題に挙げている（安丸、2001、12 頁)。

本稿も近代天皇制に対して同様の観点をとりつつ も、その問題関心は些か異なる。その関心は、第一に、 農業と近代天皇制とがどのように慗累 ${ }^{(1)}$ を持ちえた のか、あるいはもち得なかったのか、第二に、植民 地政庁がいかに近代天皇制を自分たちの業務に関連 付け効果を得ようとしたのかという点にある。国民 統合からもう一歩踏み込んだ地点における近代天皇 制の姿を明らかにしたいのである。本稿ではこのよ うな関心のための分析対象として、植民地樺太にお 
ける篤農家事業（以下、「樺太篤農家事業」と呼称） をとりあげる。

その理由は、第一に、樺太篤農家事業が昭和天皇 の即位の礼、所謂「昭和の大礼」(以下、「大礼」)を 大きな契機としている点、第二に、この樺太の篤農 家事業の高まりが、他の地域の類似した運動・事業 と連動したものではない点に求められる。

本稿の課題は、第一に、樺太農政が樺太篤農家事 業を通じて近代天皇制をどのように利用したのかと いう点を事象レベルで明らかにすることであり、第 二の課題は、樺太の篤農家事業において、近代天皇 制と農業とのあいだにどのような慗累のロジックが 用いられたのか、またそれがなぜなのかを論理レべ ルで明らかにすることである。

本稿の分析においては、樺太庁刊行物や経済調查 などの政策資料、樺太現地で発行された新聞や雑誌 などのメディア資料、大礼については内閣局刊行物 や官報などを用いる。

\section{2. 近代天皇制における「巡幸啓」と「式典」}

大日本帝国憲法は 1889 年に発布、翌 1890 年に施 行となる。この時期は日本憲政にとって大きな画期 となるだけではなく、他の面から見ても大きな画期 であったと指摘されている。形式的に見ても、1989 年には、教育勅語が発せられ、「御真影」の交付も始 まっている。

T. Fujitani（1998）は、B. Anderson（1991）が、想 像の共同体」への帰属意識が誕生するひとつの前提 条件として、「出版資本主義」による「同時性」を強 調している点をふまえ、1889 年の明治憲法発布式以 降は、国民統合の手段として天皇が関与するイベン トが、それまでの「巡幸 (imperial tour)」から、よ り近代的な一連の「式典（national ceremonial）」へ と移行する時期にもあたると論じるのである。

しかし、原武史（2001）は、巡幸を「時代遅れ の儀礼様式」(フジタニ、1994、222 頁) とするこ の Fujitani の見解を批判する。原は明治・大正・昭 和の各代の天皇の巡幸啓の事跡を検討し、巡幸啓が 1889 年以降もなお国民統合の装置として充分に機能 していたと述べる。つまり、徳川体制では「将軍が 幼少であろうが暗愚であろうがその実像を人々が意 識することは全くといってよいほどなかった」(原、 2001、218-219 頁）のに対して、「明治以降の日本は 天皇の存在を国民レベルで位置づけなければならな い時代に入った」（原、2001、369頁）のであり、そ
の際に天皇の「身体性」が問われたのである。「身体 性」が問われるとは、単に視覚化されるか否かとい うだけではなく、その個性も天皇との繋累を成り立 たせるために問われるということだと本稿は考える。

本稿では、昭和天皇の皇太子期の樺太「行啓」を ふまえつつ、「式典」としての大礼の意義を検討する。 従って本稿は植民地農政の観点から、「式典」を「対 象化して解析する」近代天皇制研究として位置づけ られる。なお、本稿で言う「式典」とは具体的に大 礼そのものだけでなく関連事業を含む。

\section{3．内地農政と近代天皇制}

原のいう「可視化された帝国」が成立することに よって何が起きたのであろうか？巡幸啓の際に沿道 に居並ぶ国民的身体が形成されるというだけである うか? 原は「可視化された帝国」の完成を十五年戦 争期においている。日本近代の国民統合をめぐる議 論において、しばしばその議論は所謂戦時体制期の ナショナリズムの昂揚を説明するためのものとして 意義を確保される。しかし、そうした極限的状況の 中でしか国民統合ないし近代天皇制の問題は問い得 ないのであろうか? 本稿が「農業」という「産業」 に対象を求めるのは、この問い故である。戦争をし ようとしまいと農業は営まれ続けて来たし、いくで あろう。

したがって、これまでの農業・農政・農村史研究 が近代天皇制の問題をどのように扱ってきたのかを 把握しておく必要がある。本節ではまず内地農民運 動史研究 ${ }^{(2)}$ の分野において近代天皇制の問題がどの ように扱われていたのかを確認する。

坂根嘉弘（1990）は、戦後の農民運動史研究には 栗原百寿の系譜と宇野経済学の二つの系譜があると している。その双方の関心は、主に明治・大正期や 農村恐慌時の小作争議の展開にある。しかし、近代 天皇制との関連で見れば、明治・大正期の小作争議 よりも、日露戦後の地方改良運動や 1930 年代の農村 経済更生運動の中に着目すべき現象が起きている。

不破和彦（1978）によれば、地方改良運動では「イ デオロギー的国民統合策」が重視され、1908 年の戊 申詔書発布後には「篤行者表彰規定」が設けられ、 近代的な行政機構に国民意識をもって取り达まれる ような「天皇制・国家主義イデオロギーによって教 化訓育」された「村民」の創出が図られた。後述の 山崎延吉もこの運動の重要人物であった。

森武磨（2005）は戦間期農村における下からの農 
民運動と上からの農民運動の対抗関係をへゲモニー 論によってとらえ、1933 年を画期として農村支配体 制が「大正デモクラシー」から「昭和ファシズム」 へ転換したとする。そして、そこで大きな契機とな るのは農村経済更生運動による農村の再編である。 大門正克（1994）は農村経済更生運動の特徵として、 第一に農村の経済的組織化、第二に農村の社会的組 織化、第三に運動の担い手として広範な村民の指定、 第四に前記 3 点を促進するための「経済更正の精神」 の喧伝、を挙げている。この第四点は、経済観念・ 勤労精神の発揮、郷土意識の発揚、国民精神の高唱 という内容を持っていた。第三点では、ある人物群 への名指しと動員が行なわれた。それが「中心人物」 「中堅人物」である。簡潔に言えば、「中堅人物」と は村内の自作農中堅·自小作上層であり、「中心人物」 とは彼らを指導する村内イデオローグであり、これ らの人物群は国民高等学校（農民道場）などで養成 された（森、2005）。この養成を担当した加藤完治や 山崎は、山形自治講習所や新風義塾において「愛国 的農民」「皇道農業」「天皇帰一」などの観念による 農業教育を行なっていたイデオローグであった（浜 田、1977）。このように農村経済更生運動を通じて、 近代天皇制は内地農村に入り込まんとした。

さて、これらの人物群は「村民」「中心人物」「中 堅人物」と名指されたのであり、本稿が直接関心を 持つ「篤農家」と名指されたのではなかった。この 「篤農家」あるいは「老農」という名指しに関心を持っ たのは、内地農民教育史の分野である。

赤司政雄（1973）によれば、「篤農家」という言 葉が公式な形で現われたのは、小作争議が激化する

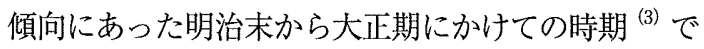
あった。前述の山崎が愛知県農会主催の全国篤農家 懇談会を 1910 年に開催したほか、各地の府県農会も 地主篤農家大会などを開催するようになった。これ らの場における「篤農家」とは自作農が中心で、か つての老農のような技術指導者ではなく地主一小作 関係の調停者として位置づけられた ${ }^{(4)}$ 。

以上の如く内地農民運動史・農民教育史には二種 類の名指された人物群がいた。ひとつは「村民」「中 心人物」「中堅人物」であり、もうひとつは「老農」「篤 農」である。本稿では、すでに農業を通じてある程 度の実績を有するごく少数の有力な人物群である後 者を「既存人物」これから育成されるべき対象とさ れた各農村内における各階層内の若手や階層の代表 者、ないしは国民化の対象となった人物群である前 者を「育成人物」と呼ぶ。しかしいずれにしろ、樺
太篤農家事業の契機を 1928 年の大礼におくのであれ ば、時期的な連動性が認められず、それが樺太農政 の独自の活動であったと考えることができるのであ る。

\section{4. 植民地農政と近代天皇制}

樺太の近代天皇制を問う前に、他の植民地、特に 朝鮮での近代天皇制を確認しておく ${ }^{(5)}$ 。

植民地朝鮮の支配イデオロギーには段階的変遷が 認められるものの、一貫して朝鮮においては異民族 支配のイデオロギーの中枢に近代天皇制は取り込ま れていた（朴、2003）。同様のことは台湾についても 駒达 (1993) や若林 (1992) によって指摘されている。

さて、次に植民地農政と近代天皇制の慗累および 「篤農家」という語の使われ方について確認する。朝 鮮植民地農政において、1910 年代に「篤農家」とい う言葉が見られる。そこで名指された朝鮮農民とは、 朝鮮農政の提示する農事改良メニューを熱心に寒行 する在村耕作地主であった（松本、1998）。1910年 代には地主会も組織されていたが、官製団体であり 活動は有形無実であった。しかし、1919年の三・一 運動を機に系統農会の設立準備が進められ、1926 年 には朝鮮の系統農会が成立されることとなる。この 系統農会が構成員を全農民に広げた一方で、地主の みを構成員にしぼった「地主懇談会」も新たに組織 された。朝鮮農政と朝鮮人地主が手を結ぶことによ り、日本一朝鮮間の民族支配対立が、地主一小作間 の階級支配対立という形にすり替えられようとした。 また、この「地主懇談会」の名称は実際には様々で「篤 農家懇談会」という名称も見られた（堀、1976）。こ れは 1920 年代の朝鮮農政においても、「篤農家」と は地主層を対象とする言葉だという 1910 年代の認 識が引き継がれていたことの証左であろう。しかし、 その一方で、1920 年代には反日本帝国主義的な性格 を持つ小作人組合も各地で結成されるようになった （大和、1982）。

1930 年代には $1929 \cdot 30$ 年の農業恐慌による朝鮮 農村の疲弊を解決すべく「農村振興運動」が起こさ れた。しかし、そこで目指されたのは地主一小作関 係の改善ではなく自力更生という道であった。富田 晶子によれば、「準戦時下の農村振興運動は『皇民 化』の名による戦争動員体制形成への布石」(富田、 1981b、96 頁）であり、「総督府は『自力更生』の諸 矛盾に対処すべく、ファッショ的イデオロギー注入 をはかっていく」(富田、1981a、166 頁) こととなっ 
た。その「イデオロギー注入」の対象となったのが、「中 堅人物」と呼ばれた人物群であった。朝鮮農政は従来、 農村支配を旧来の在地両班層ではなく中間層として の新興地主層に担わせようとしていたが、この段に なってその役割を朝鮮農政が直接育成した「中堅人 物」に期待するようになったのである ${ }^{(6)}$ 。前述の山 崎はこの農村振興運動においても起用されており、 特に 1935 年の「心田開発」政策以降は内地の農村経 済更生運動同様に、「農民道」「皇国農民」「天皇帰一」 といった観念が教え达まれ、朝鮮の農村に神道祭祀 を導入することさえ試みられた（青野、1991）。

以上の内地抢よび植民地朝鮮の農民運動史・農民 教育史から次のことが指摘できよう。第一に、既存 人物に用いられる「篤農家」「老農」といった名指し に対して、育成人物に対しては「村民」「中堅人物」「中 心人物」といった名指しが用いられた。第二に、近 代天皇制が関連するのは、後者における天皇制イデ オロギー教育においてである。すなわち各戦後・戦 時体制に対応するための「村民」「皇国農民」の養成 が図られた。第三に、この後者は農村社会の再編の 一環として位置づけられていた。内地においては地 主一小作階級支配関係、朝鮮においてはこれにさら に日本一朝鮮民族支配関係がその基底にある。ただ し、これらの緊張関係を抜本的に解消することが目 指されたわけではなく、その弥縫や㩊蔽が図られた。 第四に、これらの人物群の名指しには内地之朝鮮の 間に時期的連動性と史的文脈の類似性は認められる が、それぞれは内地農政、朝鮮農政という別個の状 況と活動の所産であった。また最後に述べ添えてお きたいのは、内地にしろ植民地にしろ、農業・農民 と「式典」、特に大礼との、観念レベルではなく、現 場レベルすなわち農政のレベルでの関係性について 論じた研究が殆んど見られないという点である。こ の点からも本稿の意義を見出せよう。

\section{5、樺太農業・農民史の現状と課題}

竹野学が指摘するように、植民地史研究の中でも 樺太史研究は立ち遅れている。それでも 1990 年代 以降は、対象領域の拡大や資料基盤の充実に伴っ て、各分野での研究が進展・多様化している（竹野、 2008)。農業史の分野でも、北大植民学派 ${ }^{(7)}$ 以来の 㮖太農業史観を払拭する竹野（2001）の研究を始め として進展が認められる。しかし、農民運動史、農 民教育史といった分野の研究は未開と言わざるを得 ない。このことは次のことからも示されよう。モー
リスンスズキ（2002）は樺太（農業）移民像として、 単純なアメリカン・ドリーム的な像を結んでいる。 その一方で、三木 (2008) は悲壮感を抱いて離郷・ 渡島する移民像を結んでいる。この二つの移民像は 一見矛盾している。この相違は何に基づくのか。

まずモーリス＝スズキであるが、検討する限りこ の記述は本庄睦男や寒川光太郎などの当時を知る作 家の作品内記述を基にしている。「実態」の考察抜き に、表象から移民像を結ぶというこの方法自体首肯 し得ないものであるが、これはまた同時に移民像を めぐる実証的研究の不足を示すものでもある。三木 の記述の根拠は、三木自身の研究（三木、2003）に 求められる。三木は当時発行されたあるパンフレッ トから農業移民のライフヒストリー分析を行なった。 このパンフレットとは『樺太農家の苦心談』(樺太 庁農林部、1929b）であり、ここに登場する10名の 人物は、本稿が対象とする「篤農家」と名指された 人物群である。しかし、三木は分析において、まっ たくこの点を加味していない。もちろん、三木の関 心は「移民」の過程にあるのであり、渡島後の社会 や生活にはないし、これらの人物群は「篤農家」と して渡島したわけでもないので、この点から三木の 研究自体を批判する必要はないであろう。また竹野 （2001）は資料のひとつとして『農家経済調査』(樺 太稙民課、1933）を用いている。この調査の中では、 サンプルとしての一般的樺太農家だけではなく、特 別に節を設けて樺太篤農家の経営データも記載され ているのだが竹野はこれにふれていない。竹野の関 心は樺太農業の一般的情況にあり、特別なカテゴリー に類する農家の経営状態を顧みる必要は無かったか らである。三木 (2006) と竹野（2001）は樺太篤農 家について若干の言及をしてはいるが、ごく簡潔で あり樺太農政上の位置つけについて充分な考察はな されておらず、近代天皇制との関係性までは視野に 入っていない。三木や竹野が不問に付したこの「篤 農家」という特別なカテゴリーから、樺太移民社会 史および農業史にアプローチするのが樺太史研究に おける本稿の位置であるといえる。

\section{6. 樺太と皇族}

樺太に関連した皇室イベントは皇太子行啓と大礼 だけではなかった。そのほかの皇室と樺太との関連 を示すことにより、樺太に扔ける皇太子行啓と大礼 の位置を確認する。

最も早い樺太と皇室事業の接点は、1912 年の明治 
天皇大培に際しての「御下賜金」であった（樺太庁、 1936)。

大日本農会は 1881 年の設立時にその最高職であ る会頭に北白川宮能久親王を迎えて以来、現代にい たるまで最高職には常に皇族を迎えている。そして 1894 年から「農事功績者」への表彰事業を開始する。 戦争によって中断される 1941 年までに、国内外の 10,240 名が受賞している。樺太からは、佐藤唯吉(1919 年)、須賀清次郎 (1928 年) ら4 名が表彰されている。 1919 年は、関東州と満州からも初めて表彰者が出た ほか、台湾の漢族、朝鮮の朝鮮人からも初めて表彰 者が出た年であった（大日本農会、2001）。

行啓については、皇太子裕仁 (1925 年) を皮切りに、 7 名の皇族が 1936 年までに行なっている。その後の 戦時体制においても、東久雨宮稔彦王、昌德宮李垠 王などが行啓を重ねており（ГА C O,$\Phi .2$ и, Оп.3, Д .12)、1925 年の皇太子行啓、1928 年の大礼と昭和 天皇中心の皇室イベントが続いた後に定期的な各皇 族による樺太行啓が始まったことが確認できる。

\section{7. 昭和の大礼の中の植民地}

昭和の大礼およびその関連事業を本稿では「大礼 事業」と呼ぶこととする。近代天皇制の一環である この大礼事業を樺太農政がいかに独自に樺太で展開 させたのかを明らかにするのが、本稿の課題の一つ である。しかし、そのためにはそもそも中央政府が この大礼事業をどのように意味づけていたのかとい う点を検討しなければならない。

昭和の大礼とは簡潔に述べれば、1926年の大正天 皇崩御を受け践袮した昭和天皇の即位礼である。『昭 和大礼要録』(以下、『要録』) (内閣大礼記念編纂委 員会、1931）によれば、即位礼自体は、1928年 11 月 10 日に京都御所にて行なわれ、引き続き諸儀を済 ませた後の 14 日に大嘗祭が行なわれた。このため昭 和天皇は 6 日に行幸し、27 日に皇居へと還幸した。

大礼事業の中で、樺太篤農家事業と関連するのは その中の恩典就賞「特例銀杯下賜」と「移植民功労 者表彰」である。またこれらの事業の意図を明確に するために、後者と対にされていた事業である「社 会事業功労者表彰」についても詳解しておく ${ }^{(8)}$ 。

「特例銀杯」の対象者は「孝子にして且節婦」 17 名、 「孝子」15名、「節婦」9名、「忠僕或は忠婢」8名、「実 業に精励」 2 名、「公衆の利益」49名であるが、㮖太 も含めて「外地」の者や、農業に関与する者で顕彰 された者がいるのは、「公衆の利益」のみである。ま
た、公衆の利益」以外の項目は明らかに儒教的な徳 目に沿ったものである一方で、「公衆の利益」の内実 は些か不明確であるから、この点を明確にする必要 があろう。

地域別の内訳を「所在地」と「活動地」に分けて 表一 1 に示した。「所在地」については、「不明」の 10 名を除くと 3 分の 2 が内地である。しかし、その 一方で「活動地」については逆に 3 分の 2 が外地な のである。また受賞者 49 名のうちの 4 分の 1 にあた る 12 名が漢族・朝鮮人、さらに 1 名が台湾少数民族 と判断できる。受賞理由も多様であり、たとえば樺 太の 4 名については、教育 (佐々木時造)、農業 (須 賀清次郎)、土木建築 (高山小枝丸)、水産業 (保知清吉) となっている。

以上から、「特例銀杯」(公衆の利益) は主に外地 で活動する日本人や、植民地政府に協力的な外地の 被支配民族を重点的に表彰する姿勢が認められるの である ${ }^{(9)}$ 。

次に、「移植民功労者表彰」・「社会事業功労者表彰」 の検証に移る。実のところ、本稿が依拠している『要 録ににはこの二つの表彰に関する記載はない。しかし、 樺太篤農家自身も、また樺太現地メディアもこの表 彰が大礼に関連したものだと認識していたのは明ら かなのである ${ }^{(10)}$ 。したがって本稿では、この二つの 表彰事業が、少なくとも当事者たちにとって大礼と 関連付けられていたという意味で大礼の一環とみな す。

さて、表一 1 のごとく、「特例銀杯」で指摘したこ とがこの二つの表彰事業ではより明瞭になっている。 漢族・朝鮮人 · 少数民族の名前が双方に見当たらな い一方で、「社会事業功労者」には北海道アイヌの研 究・教育に貢献したジョン・バチェラーのような欧 米人が見受けられる。さらに、「特例銀杯」の例から 類推するに、所在地が内地の地名で記載されていて も活動地は外地である可能性は極めて高い。以上を 鑑みるに、「社会事業功労者」は内地で活動した日本 人・欧米人を、「移植民功労者」は外地へ進出した日 本人を対象としていると判断できるのである。樺太 の場合、後者の対象となった 4 名はすべてその後に 篤農家と称せられる人物たちであり、内地から樺太 へ渡り六殖した人々であった。

かくして大礼事業に抒いて、内地／外地、日本人・ 欧米人/被支配民族は明瞭に意識・区別されており、 さらにこの区別は小森（2001）が指摘した「日本型 植民地主義」の「文明／野蛮」観とも一致している と言える。ここで取り上げた大礼の顕彰事業は、そ 
表一 1 昭和の大礼における顕彰者内訳

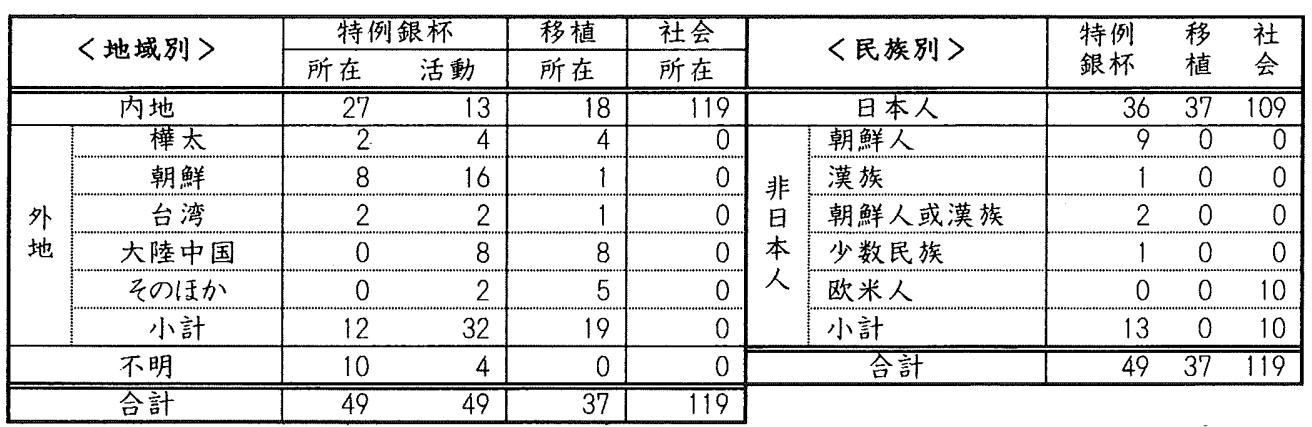

出所) 内閣大礼記念編箘委員会(1931)、『官報』(1928年11月22日付[号外]、同23日付、同29日付、同30日付、 同 12 月 10 日付、同 29 日付)上り筆者作成。

注 1)「特例銀杯」と汉「公衆の利益を興したる廉に依」る「特例銀杯」授与者、「移植」とは「移植民功労者表彰」受賞者、 「社会」とは「社会事業功労者表彰」受賞者、「所在」は受賞者の所在地、「活動」は活動地をさす。

注2）「特例銀杯」の「大陸中国」とは具体的には「満洲」「関東州」。

注3）「特例銀杯」の「その任小2名の方、フィ片ン(1)、海外移住者支援(1)。

注4)「不明」とは、名前に添之書きされる住所の部分に勲等などが記载され、かつ受賞理由からも判断できない場合。

注5）「移植」の「大陸中国」は、奉天(1)、牛荘(1)、長沙(1)、北京(1)、吉林(1)、済南(1)、鉄嶺(1)、関東州(1)。

注6)「移植」の「そのほか」仕、バ多ビヤ(1)、バウルー(1)、ベルー(1)、アルゼンチン(2)。

の典型的な顕われであり、具体的に言えば日本人 の外地進出を積極的に称揚する植民地主義の顕現で あったと理解できるのである。そして、ここで樺太 は完全に外地として扱われていた。

大礼の大嘗祭に供される米・粟など（庭積机代物） を生産する農民は「正奉耕者」と呼ばれ、内地道府県、 朝鮮、台湾、関東州、南洋、そして樺太から計 111 名が選ばれた。『要録』には槿太からは齋藤政次が「精 粟」を献納したという記録がある(11)。このように大 礼においては内地の農業だけではなく外地の農業も 「式典」に結び付けられたのである。

\section{8．樺太農政における「篤農家」}

では、樺太では「篤農家」はどのようにして、生 まれたのであろうか？

領有 2 年後の 1907 年に総合行政機関である樺太 庁が設置され、農水省管轄の内地農政から独立した 樺太農政が始まった。1920 年代中葉には樺太は帝国 内の人口・食糧問題の解決地として位置づけられた。 朝鮮・台湾のような投資型植民地とは異なる移住型 植民地としての役割を㮖太庁も自認し、農業移民政 策を拓殖の根幹としたのであった（竹野、2000）。

「篤農家」という言葉は、大礼以前からすでに樺太 のメディアには現われていた。各種の顕彰事業自体 が「篤農家」という言葉を使っていないにも関わらず、 メディアは用いており、この時期には樺太でもこの 言葉がある程度人口に膾采していたとうかがえる ${ }^{(12)}$ 。
大礼から間もない 1929 年の $1 \cdot 2$ 月に「樺太庁殖 民課農畜産大講演会」が行なわれ、3名の樺太農家 が島内を講演して回った。同年 6 月にはこの巡回講 演会の内容が『篤農家講演集』（以下、『講演集』）と して刊行される。この「緒言」には、「本編篤農家講 演集は昭和三年度島内篤農者として表彰を受けたる 佐久間喜四郎氏、齋藤政次氏、的場岩太郎氏の諸氏」 という表現がある。また本文によれば須賀清次郎も 講師に選ばれてはいたが、病床にあったため参加で きなかったという。この 4 名は大礼における「特例 銀杯」「移植民功労者」「正奉耕者」の対象者である。 そして、同年 8 月には『㮖太農家の苦心談』(以下、 『苦心談』）が刊行され、10名の樺太農家が紹介され る。このパンフレットの「序」には、「篤農家」なる 表現は現れていない。しかし、時をおいて 1933 年に 樺太農政が作成した調査報告書『農家経済調查』に は、前述のように 1929 年度の「篤農家」の経営デー 夕が掲載されている。この「篤農家」10名と『苦心談』 の 10 名とは完全に一致する。

かくして、1928年の大礼を契機とした上記の樺太 篤農家事業を通して、これらの既存人物が樺太農政 により独自に「篤農家」と名指され生文出された であった。(表-2)

メディアについてみると、1931 年には雑誌『樺太』 に佐久間、齋藤、須賀らのインタビュー記事が現わ れるようになる。『樺太日日新聞』に目を向けると、 篤農家に関する記事は、 1928 年に 8 件、 29 年に 12 件、 30 年に 2 件となり、その後はほとんど見られなくなっ 
表一 2 樺太篤農家一覧

\begin{tabular}{|c|c|c|c|c|c|c|c|c|c|c|c|c|c|}
\hline \multirow{2}{*}{ 名前 } & \multirow{2}{*}{ 行啓 } & \multirow{2}{*}{ 特銀 } & \multirow{2}{*}{ 移功 } & \multirow{2}{*}{ 正耕 } & \multirow{2}{*}{ 農会 } & \multicolumn{3}{|c|}{ 樺太篤震家事業 } & \multirow{2}{*}{$\begin{array}{l}\text { 家族 } \\
\text { 数 } \\
\end{array}$} & \multirow{2}{*}{$\begin{array}{l}\text { 徙業 } \\
\text { 者数 }\end{array}$} & \multirow{2}{*}{$\begin{array}{l}\text { 耕地 } \\
\text { [ha] }\end{array}$} & \multirow{2}{*}{\multicolumn{2}{|c|}{$\begin{array}{l}\text { 曹外 牛 馬 } \\
\text { 所得 [頭] [頭] }\end{array}$}} \\
\hline & & & & & & 講演 & 苦心 & 調査 & & & & & \\
\hline 須賀清次郎 & $\overline{0}$ & $\bar{O}$ & $\overline{0}$ & $\bar{O}$ & $\bar{O}$ & $\triangle$ & $\bar{O}$ & $\overline{0}$ & 11 & 8 & 17.90 & 0.36 & 72 \\
\hline 佐久間喜四郎 & 0 & & 0 & & & $\overrightarrow{0}$ & 0 & 0 & 4 & 4 & 23.06 & 0.10 & 82 \\
\hline 的場岩太郎 & 0 & & 0 & & & 0 & 0 & $\mathrm{O}$ & $\frac{1}{7}$ & 4 & 8.80 & 0.05 & 91 \\
\hline 齋藤政次 & & & & 0 & & $\mathrm{O}$ & 0 & 0 & 10 & 3 & 12.50 & 0.50 & 121 \\
\hline 塩澤広吉 & $\mathrm{O}$ & & 0 & & & & 0 & 0 & 1 & 1 & 5.40 & 0.00 & 31 \\
\hline 大堀要八 & & & & & & & 0 & 0 & 9 & 2 & 7.75 & 0.32 & 03 \\
\hline 藤本栄吉 & & & & & & & 0 & 0 & 3 & 4 & 6.80 & 0.03 & 02 \\
\hline 吉田清五郎 & & & & & & & O & 0 & 7 & 2 & 4.50 & 0.19 & 02 \\
\hline 布村伊次郎 & & & & & & & 0 & 0 & 4 & 2 & 4.60 & 0.27 & 01 \\
\hline 三輸栄正 & & & & & & & 0 & 0 & 2 & 2 & 9.55 & 0.00 & $\begin{array}{ll}0 & 2\end{array}$ \\
\hline
\end{tabular}

出所）樺太庁農林部(1929a)、樺太庁農林部(1929b)、樺太庁殖民課(1933)、『樺太日日新聞』(1928年2月16 日号、同 10 月 7 日号、1929年1月11日号、1941年10月21日号)㣌筆者作成。

注 1)「行啓」=1925 年の皇太子裕仁行啓時の拝謁者、「特銀」三昭和の大礼の「特別銀杯」授与者、「移功」二昭 和の大礼の「移植民功労者」顕彰者、「正耕」二昭和の大礼の「正奉耕者」、「農会」二大日本農会による顕 彰者(1928 年)、「講演」=1929年の樺太庁主催の大畜産講演会に講師として参加、「苦心」二『樺太農家の 苦心談』に登場、「調査」ニ『農家経済調査』に「篤農家」として、1929 年時の経営データが揭載。

注 2) 須賀清次郎も講師として選ばれていたが、病床に伏せたため講演集には名前は残っていない。

注 3）「農外所得」は所得にしめる農畜産業以外の所得の占める割合をさ文。

てしまう。樺太で「篤農家」という言葉が取りざた されたのは、1928-31 年の間と言えるのである ${ }^{(13)}$ 。

樺太篤農家事業が $1928 \cdot 29$ 年を、メデイアへの露 出が $1928-31$ 年あたりをピークとするならば、こ れらの時期は樺太農政および樺太農業にとってどの ような時期であったのであろうか？この点を検証 し、樺太農政にとっての「篤農家」の位置づけを明 らかにする。

1907 年の樺太庁設置後、1912 年に樺太農政は正式 な農業移民制度を開始する。その後、改正を幾度か 重ねながら、1928 年に集団移民制度と自由移民制度 の併用という形で固定化させ、1932 年には集団移民 制度の対象を島内出身者にも拡大する。そして翌 33 年には農業移民事業自体の募集宣伝を中止してしま う。一方、1932 年の年末から雑誌『樺太』の誌面上 で「樺太農業論争」 ${ }^{(14)}$ が繰り広げられ、メディア上 に樺太農政担当者や樺太庁中央試験所のスタッフら の発言が活発に現われるようになる。そして、1934 年には拓殖計画に伴い「樺太農法経営大体標準」（以 下、「標準」)、つまりは農家経営モデルが樺太農政に よって画定されることとなる。ここから指摘できる のは、件の 1928 年を㮖太農政の転換期とみなせるの ではないかということである。すなわち、移民制度 の調整から、経㗬宅宁学方調整への転換である。こ れを実証するために、数量的なデータに目を向けよ う。

まず、1928 年以前の農政パンフレットを検討する。 1923 年には『樺太之産業、1925 年には『樺太の農業』
が刊行される。双方に農家の経営データが揭載され ている。しかし、この二つの間には大きな隔たりが あるのである。たとえば経営面積を比較すると前者 が3.7ha であるのに対して、後者が 8.8ha なのである。 わずか 2 年間で島内の 1 戸あたりの平均経営面積が 2 倍以上に増加したなどと考えるには無理があるし、 そもそも統計からいっても後者が純然たる平均数値 であるとはみなせない。むしろ、ほかの項目を検討 しても「標準」で設定された数値に近いと言えるの である。つまり、1925 年の段階である程度、理想的 な樺太農業経営像が樺太農政内部に形成され始めて いたのであり、また同時にそれを体現するような実 例も樺太内に実際に生まれ始めており、『樺太の農業』 の数值は模範的な農家から得た調查結果であったと 推測できる。北大植民学派の高倉新一郎は戦後に出 版された『北海道拓殖史』に抢いて樺太農業を総括 する文章の中で、「樺太の農業は、領有当初から始ま つたが、最初から眞面目な農業者は尠なかつた。漁 業或は商業の片手間に農業を營むか、農業で自家食 料を得て雜業に從ふものが多かつた。（中略）農を專 業とする農家と農村が出現したのは昭和三年以後の 事に過ぎない」(高倉、1947、293 頁) と述べている。 高倉がここであげている画期「昭和三年」はまさに 1928 年なのある。

では、樺太篤農家の経営は、「標準」に影響を与え ることになったのであろうか。この点を、「標準」に 示されたモデルと『農家経済調查』の中の篤農家経 営データを比較することで検証する。「標準」で示さ 
れたのは端的に言えば、食料・飼料・肥料を自給す る有畜 (牛) 家族経営専業農家モデルであった。樺 太篤農家 10 戸のデータを比較すると各項目について バラつきが多いものの、中核的な篤農家 5 名につい ては有畜（牛）農業を実現していることと、耕作面 積については 6 名の篤農家が「標準」(7.5ha) を淩 駕していることを指摘できる。樺太農政は樺太篤農 家を基にして「標準」のモデルを構築したのではなく、 自身の諭理に沿ってモデルを構築し、その際に樺太 篤農家のデー夕を成功例として部分的に参照したと 考えられる。また完全に参照するには篤農家間の経 営にバラつきが多すぎる。ただし、1929 年の「篤農家」 調查に大礼に無関係な 5 名が加えられている点を鑑 みるに、1929 年時点では篤農家の経営デー夕を参照 しょうとしていた意図はうかがえるのである。

領有後、露領時代のロシア系住民の大半は本国送 還されていたため、樺太農政はまず農業移民の招来 を重視する必要があった。しかしやがて、農業移民 の定着という問題を重視する必要が生じてきたので ある。1928年はこの転換期であったと言えるであろ う。樺太農政は定着の成功事例を内外に示す必要性 に迫られていたのである。そして、樺太篤農家は成 功事例として、樺太農業の一里塚としての役割を担 わされたし、またそれ以上の役割は期待されなかっ たのである。このことは、1930 年代に入り官民で農 業経営モデルが議論される一方で、その議論の中で 彼らが参照項にほとんどされなかったことからも理 解できる。つまり、樺太農政にとって、樺太篤農家 とは、内においては経営モデル構築のための間接的 根拠、外に向かっては内実を不問にした形での樺太 農業の成功事例としての位置づけを与えられていた と言えよう。しかし、このことは 1930 年代の動向と 結び付けてこそ言い得る見解であり、1930年代の樺 太農政にとっての位置づけとも言える。1928年のそ の段階での樺太篤農家の位置づけは、むしろ近代天 皇制との慗累の中に見出されるであろう。

\section{9. 樺太農政と近代天皇制の繋累の ロジック}

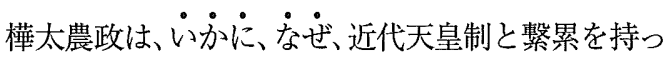
たのか?

この点を『講演集』『苦心談』の中の篤農家たちの 発言から検討する。ただし、これらを単純に彼らの 生の語りとして扱うことはできない。全編樺太農政 による創作という極論は退けるとしても、編集に関
わっている以上、ここには樺太農政にとっての「篤 農家」像が既存人物を用いて間接的に提示されよう としている意図を認めないわけにはいかない。

検討に際して注目しておきたいのが、昭和天皇が 有していた二つの個性である。ひとつは「樺太行啓」 をした天皇、もうひとつは「田植」をする天皇 ${ }^{(15)}$ と いう個性である。

第一の個性である 1925 年の行啓と 1928 年の大礼 とは常に結び付けられた。

畏くも皇太子殿下本島行啓の砌には樺太廳で奉 拝の榮譽を賜り御大典には移殖民事業功勞者とし て内務大臣から表彰狀及銀牌を授與せられ今では 皇恩の無窮なるに唯々感泣して居る次第でありま す。一佐久間 (『苦心談、11頁) このように、大礼での顕彰は行啓とそれに際した 謁見とを再度思い起こさせる。これは謁見した農家 と大礼で顕彰された農家とが重なっているからであ る(表- 2 参照)。

では第二の個性「田植」は樺太篤農家にどのよう な意味を持ったか。

最後に最も有難く力强い事は 聖上陛下に於か せられましては御踐袮早々御自ら稲を御試作なさ れ我々農民へ範を垂れ給ふた事であります從來農 民を土百姓等と嘲笑した者共は顔色がない筈であ ります斯の如き期難い聖上陡下を戴き又た今回の 如き長官閣下の思召と謂い有難涙が流れるのであ ります。吾々農民は自他共に大いに努力し御高恩 の萬分の一に報ひ奉らんことを希望して止まぬ次 第であります。一齋藤（『講演集』、23 頁） もちろん、この点は樺太以外の地域にも共通し得 る点ではある。しかし、樺太の特殊な事情を拾い直 して、解釈する必要がある。すでに述べたように当 初樺太には農村など存在せず、また内地の農法さえ すんなりと移植できるわけではなかった。そういう ことから考えれば篤農家とは前例のない樺太の農村 と農業とを作り上げた人物群だったのである。彼ら の多くは村内の要職を務めるたたき上げの指導者で もあった。行啓（1925 年）一田植（1927 年）一大礼 (1928 年)、という一連の流れを彼らの視点から捉え なおしてみよう。行啓時に彼らは農民として皇太子 と謁見を許され、その践袮後には国家の絶対的権威 である天皇が自ら田植をしたことを通じて、彼らの 生業である農業が天皇によって顧みられる価值のあ るものだと感得した。そして大礼において改めて彼 らは天皇により樺太の農民として「見られた」ので ある。艱難辛苦に満ちた血と汗のにじむ樺太農業は、 
この 1928 年に改めて、天皇の視界に入る価值のある ものとして顕現させられたのである。

大賞祭に際しての「正奉耕者」はまさに古代王権 の儀礼である「食国」(16) になぞらえられよう。しかし、 樺太篤農家はおろか、樺太農政官僚さえ「食国」の「伝 統」を関知し連想し得るかは定かではない。けれども、 「食国」儀礼はそうした「伝統性」が意識されなくと も、象徴的な意味を持ちえるであろう。樺太は稲作 不可能地域であり、大礼において米を献穀できなかっ たのは樺太のみであった。原田（1993）は近世まで の日本社会において稲作の可否が「日本」の領域性 の指標となっていたとする。もしこの感覚が樺太に おいても維持されていたとするならば、稲作不可能 地域ゆえに米を献穀できなかったという事実は強烈 なるナショナル・アイデンティティの疎外を引き起 こすであろう。しかし一方で、粟であれ大礼という 極めて重要な天皇儀礼に樺太の農産物を献穀したと いうことは、樺太農業もまた日本農業であるという 認識を作り出し、その疎外を克服するのである。

こうした行啓や正奉耕者、大礼での顕彰といった 経験は個人的なものとして閉じ込められたものでは なかった。齋藤は正奉耕者に選ばれたときのことを 次のように回想している。

私の粟の出來は樺太約五萬の農民の不名譽であ

り農民の不名譽は全島民の不面目なのであります 實に私の責任は大變なものでありました心の小さ い私は若しも萬一不出來の時は夜逃げするか切腹 し様かと思つた位であります

\section{一齋藤（『講演集』、21 頁）}

樺太農民のみならず樺太島民全体を代表して正奉 耕者を体験するという感覚を篤農家自身が有してい たのである。メディアによる報道なども彼を樺太農 民および樺太島民の代表であるかのように扱った。 ここに、大礼という「式典」を通じて天皇と篤農家 に慗累が生まれ、さらに国家と農民に慗累が生まれ るというロジックが成り立つのである。

次に問うべは、その慗累が、なぜ必要だったの かという点である。樺太篤農家に共通するのは精神 主義である。樺太農政は確かに篤農家という成功事 例を得たのであるが、超人的な努力が必要になるの であれば、その精神主義を安定的に保障してくれる ようなイデオロギー、言わば拓殖イデオロギーが必 要とされた。たとえば、主食問題である。樺太農政 は樺太農家が主食を米から燕麦や馬鈴薯といった自 給作物に転換させることに腐心し続け、1920 年代中 葉から見られるようになったそうした米食撤廃論は、
ナショナル・アイデンティテイに訴えかけたり、文 化諭を立ち上げる形でこの問題を解決しようとした (中山、2008)。一方、樺太篤農家の中にも、非米食 を説く者たちがいたが、彼らの精励の根拠は家運の 再興であったり信仰心であったりと個人的でバラっ きがあった。

また農業への動機にもバラつきがあった。

私が故郷に於て如何に働きましても到底一家を 起す見込みがないと存じましたので十ヶ年北海道 出稼のことを父に嘆願致しましたが、然し父は此 の願を許して点れませんでした。(中略）占領後間 もないことであるから何か仕事があるだろうと考 へまして四月五日小樽出帆の（樺太行きの:引用者) 船に身を委ねたのであります。(中略) 何時迄人に 使はれて居ても果てしがないと考へまして（中略） 米、味噌と農具種子を買ひ手井澤に轉住しました。

一佐久間 (『苦心談』、7-8 頁)

成功事例である樺太篤農家さえ、渡島後に偶然的 に就農し、その結果として専農化し得たに過ぎない のである。「满洲」の試験移民団のように内地で特別 に教育・訓練を施されたり、表面上であれ帝国のた めにと意気込んで海を渡ったりしていたわけではな かった（工藤、1940）。従って、樺太農政にとって 篤農家は二面性を有していた。樺太農業の成功事例 であると同時に、精神面では偶然的で不十分であっ た。樺太農政は就農から精神主義まで、必然的であ るような方途を導かなければならなかった。この時 点で樺太農政は自前の農民養成機関やイデオローグ を持ってはいなかった。そのため、大礼は絶好の機 会となったと言えよう。㮖太農政は成功事例である 樺太篤農家を近代天皇制と結合させ、彼らの存在を 喧伝したのである。樺太篤農家の精神主義には普遍 性というものが無かった。しかし、国民国家において、 国民ほど普遍性を持つ名指しはない。彼らを天皇儀 礼と結びっけることで、あたかも彼らの就農・営農 と言う私的行為が、拓殖・開拓といった公的なもの であるかのように偽装を施したのである。彼らは見 事に本分を果たした国民として人々の前に引き出さ れ、ほかの国民にも同様の刻苦勉励を要求する根拠 とされたのである。

「之れ㗹て一身一家の策を樹てるのみならず、帝 國領土の開拓進展に貢献するものにして、樺太の開 拓は即ち數十万の生靈と數十億の國努とを犠牲に供 したる日露戰役をして始めて意義あらしむるものと 謂うべし」(槿太庁拓殖部、1923、6 頁) といった国 家事業たる拓殖と私的就農営農とを国民観念を媒介 
に結合させ、動員の根拠とする拓殖イデオロギーは、 さらに「式典」を介在させることでより説得力を帯 びることとなる。

ただし 1930 年代に入ると、樺太農政の関心は、既 存人物から育成人物へ、またメディアの関心も、樺 太篤農家の経験談よりも、1929 年に統合・設立さ れた樺太庁中央試験所のスタッフを始めとした植民 地エリートの科学的言説へとシフトして行ったので あった。

「標準」が策定される前年の 1933 年に提出された 樺太拓殖調査委員会の答申書と説明書の中では「須 ラク島民ノ拓殖精神タ振興シ以テ拓殖事業ノ大成习 期スルコト肝要ナリトス」として拓殖イデオロギー の重要性が強調されているし、「敬神崇跙ノ美風ハ實 二拓殖精神ノ基調ニシテ」(樺太拓殖調査委員会第一 部委員、1933、14、72頁）というような文言は、同 じく 1930 年代に内地や朝鮮において農村に這い入 ろうとしていた天皇制イデオロギーを彷彿とさせる。 また、この拓殖計画によって各地に設立された「興 農会」は「樺太拓殖道場」を行政の完全な補助のも と経営するようになる。ある拓殖農場では町村長の 推薦を受けた 15 嵗から 27 歳の青年 28 名の修練生 が共同生活を送り、宮城遥拝、国旗揭揚、神社参恠、 誓詞暗唱などの国家主義的儀礼が日課として行なわ れていた。そして誓詞には「農民道」「殖産報國」と いった言葉も見られた（松尾、1939）。

こうした動きの中で、樺太農政における樺太篤農 家たちの位置づけは樺太農業の一里塚以上のものに はなり得なかった。竹野 (2005) や中山 (2008) が 指摘する如く、1934 年以降、官製の経営モデルと官 製の精神主義や拓殖イデオロギーが現われ、それら を体現するべく育成された農村青年が樺太農政と農 業の主軸となっていくと期待されたからである ${ }^{(17)}$ 。

\section{0. 結論}

本稿の課題は、第一に、樺太農政が樺太篤農家事 業を通じて近代天皇制をどのように利用したのかと いう点を事象レベルで明らかにすることであった。 1928 年に樺太農政は転換期を迎えていた。移民制度 の調整から、経営モデルの調整への転換を図ろうと していた。そして 1928 年までにはすでにある程度の 樺太農家の成功事例が生まれており、樺太農政はこ れら既存人物の一部を表彰事業や正奉耕者の形で大 礼と結びつけた。その後、改めて「篤農家」と名指し、 成功事例として喧伝したのである。樺太の農業と近
代天皇制とは、篤農家と大礼とを媒介に結びついた のである。樺太農政は樺太篤農家が成功事例である こと自体には満足していたが、その経営内容と精神 面には満足してはいなかった。なぜならば、1928年 の時点で 1934 年の「標準」に体現される経営モデル の腹案を漠然としてであれ、すでに有しており、そ れと樺太篤農家の経営実態の間には隔たりがあった からである。また樺太農政のモデルを実現するには 精神主義が前提とされ、その普遍的な確立が要求さ れた。そして用いられたのが、国民という普遍性で あった。樺太農政は、樺太篤農家を「行啓」「式典」 と結びつけることで拓殖という国家事業に本分を果 たした国民として一般樺太島民の前に顕現させ、樺 太農民に拓殖イデオロギーを受容させる根拠を作り 出した。樺太農政は大礼に対して、単なる国民統合 以上のより現場的な利用価值を認めていたのである。

第二の課題は、㮖太の篤農家事業において、近代 天皇制とのあいだにどのような繋累のロジックがな ぜ用いられたのかを論理レベルで明らかにすること であった。樺太農政は大礼に現われた天皇を、篤農 家たちを農民として「見る」天皇として演出した。「特 例銀杯」「移植民功労者」「正奉耕者」これらのいず れも天皇が篤農家を農民として「見た」ことの所産 と理解させようとした。樺太はいまだ農民としての アイデンティティが摇らぎ明滅する空間であった。 しかし、天皇という絶対的権威によって「見られた」 ことによりそのアイデンティティは安定化する。い わば天皇の「視界」に入ることにより、農民として の自己が認証されるのである。そして樺太農政はこ の繋累を篤農家のみに占有させるのではなく、樺太 農民と名指された人々にも、メディアなどを通じて ひろく共有させようと図った。樺太篤農家事業とは、 成功事例の喧伝であるだけではなく、農民として天 皇に「見られる」体験を共有させる試みでもあった のである。天皇に農民として「見られる」ことにより、 樺太農民に自らが農民かつ国民であるのだと意識さ せ、国民の本分を果たすべく自発的に拓殖に参加す るように期待したのである。

内地や植民地朝鮮の農政が、イデオロギーによっ て異民族支配の正当化や地主支配の隠蔽を図ろうと したように、樺太植民地農政は拓殖イデオロギーを 構築せんとしていたのである。樺太篤農家事業とは、 その試みの一つであった。農政の関心が既存人物か ら育成人物へシフトする点では、内地、朝鮮と類似 しているが、その時期や状況はやはり異なる。その 基底には、階級間ないし民族間の緊張関係の調整・ 
隠蔽ではなく、農政の重要課題として「拓殖」があっ たのである。樺太を出稼地から健全な開拓地へ有成 することが樺太農政の課題であったのである。

拓殖イデオロギーの喚起を図った樺太農政は、「行 啓」や「式典」で生まれた樺太篤農家と天皇との間 の繋累を強調し、その繋累の一方を樺太農民・農業 全般へ、また一方を国家へと伸ばそうとした。その 繋累の枢要は、天皇に「国民」かつ「農民」として「見 られる」ことにあり、その意義は私的就農営農の成 功者を国家的な拓殖事業への貢献者に偽装すること にあったのである。

\section{注}

（1）本稿ではこの語を「連関」の意で用いる。支配一被支配 関係であるはずの天皇一国民（臣民）関倸はしばしば親 子関係に擬され、国民間の関係、そして民族間の関係も 兄弟関係のように擬され、慗ぎ票ねられようとした。「慗 累」の語は拘束性の他に親族関係も含意するので、上記 のような近代天皇制の特性をふまえ、本稿ではあえてこ の語を用いた。

（2）本稿では形式的に、大日本帝国憲法発布以前の領土を「内 地」それ以降に編入された植民地やそのほかの勢力圈 を「外地」と呼ぶ。

（3）一般の内地農業・農政史では、たとえば井上（1972）が 指摘しているように、1921 年や 1936 年周辺が小作争議 激化の時期として挙げられる。しかし、赤司は「地主・ 小作関係が従来の温情主義的関係から対抗関係に変化 し、小作争議が激化する傾向にあった」(赤司、1973、 118-119 頁）として、この時期の「篤農」の実態を分析し ている。

（4）ただし農村経済更生運動に执いても再び「篤農家」とい う語が現れる。たとえば、1932・33 年には大日本聯合青 年団が「全国青年篤農家懇談会」を開催している。この 会合は農村経済更生運動の一環であり、内地各府県、北 海道、樺太から 30 歳までの 134 名の「青年篤農を招集し て時局に関する研究討議を邀げ、以って農村の更正に資 するあらん」という名目で開催された（大日本聯合青年 団、1932)。1932 年大会では樺太からも1名参加してい るものの、この人物は樺太篤農家の範鲒には入っていな いし、ここでの「篤農家」という名指しは育成人物に対 するものであった。

（5）本稿が樺太との類似性を指摘される北海道の農政・農業 を比較対象としていないのは、近代天皇制を考える上で は、被支配民族による抵抗が最も強く植民地として好対 照であった朝鮮などの地域との比較から樺太農政の特色 を描くことが適切だと考えるかららである。

（6）台湾でも 1930 年代に、日本人・漢族双方の青年を対象と した農業学校が設立されて農村の中堅人物を「皇国農民」 として育成することが図られた（張、2001、199-200 頁）。 少数民族についても、皇民化政策の推進と共に村の「中 堅人物」の養成を目的とする「農業講習所」が各地に設
立された（松田、2000）。また「篤農家」という言荣も見 られ、たとえば台北州農会は「青年篤農家講習」を開催 している（台北州農会、1937）。

（7）本稿の言う「北大植民学派」とは、竹野 (2003) の言う 植民学における「北大学派」のことである。便宜上、こ のような表現を用いた。

（8）当時の『官報』においてこの二つの事業は常に並べて扱 われていた。

（9）北海道や沖縄などの「内国植民地」の人間も「公采の利益」 での夕名前が認められる。

（10）たとえば「御大典に表彰された篤農家が講演 全島農村 を行脚する 豊原功も二人参加して」(『㩰太日日新聞』 1929 年 1 月 11 日号）など。この二人とは須賀と的場で ある。

（11）ただし、樺太現地メディアでは前出の須賀も大嘗祭の机 代物として馬鈴薯を「奉耕」し収穫祭を行なうと報じら れている(須賀氏奉耕馬鈴薯収穫祭執行」『桙太日日新 聞』、1928年 10 月 7 日号)。これは『要録』では米・粟 の献嵘者しか記録されていないためであると思われる。 本稿では須賀も「正奉耕者」として扱う。

（12）たとえば、1928年 2 月 16 日の『檴太日日新聞』には「本 斗支庁に於て紀元節を卜し管内篤農家を表彰 農事組合 にも感状を贈る」という見出しが見られる。しかし、こ の際の表彰状には「篤農家」なる言葉は現われては损ら ず、「右者移住以来鋭意農業に従事し斯業の改良発達を 図り其の功蹟顕著にして他の模範とするに足る仍て木杯 を贈呈し茲に之を表彰す」という表現があるに過ぎない。 前述の大日本農会による表彰に際しても大日本農会は表 彰理由として「農業上の功績功労の顕著なる者」(大日 本農会、2001、28頁）という表現を用いているに過ざな いのに樺太現地メディアは「篤農家」という表現を用い ている。

（13）ただし、メディアが取り上げたのは本稿が取り上げる 10 名に限っていたわけではない。また 1941 年には再び「篤 農家」と名指される人物群が現われ、「土の十二戦士」な どと称されたが(荊の道を克服して農村に挙るこの凱 歌 全島篤農家建設の声 巡回座談会その一」『㮆太日 日新聞』1941 年 10 月 21 日号など)、この時期の動向に ついては、「食糧增産実行共励員」との関係なども含め て別稿に讓りたい。

(14)「樺太農業論争」については、竹野（2001）、竹野 (2005) などに詳しい。

（15）昭和天皇は「田植」をした初の天皇だった（高橋、 1994)。

（16）古代王権の服属儀礼としての「食国」と新嘗祭の関係に ついては岡田（1970）を参照。

(17) 篤農家のうちでその後の動向が判明しているものは限ら れている。前注記の「土の十二戦士」の 12 名のうちに は佐久間と三輪のみが入っている。敗戦後の 1946 年 2 月 にソ連当局が作成した南少ハリンの大規模農場のリス卜

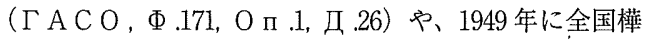
太連盟が作成した『樺太人物鑑』には三輪の名前しか見 られない。しかし、この点は世代交代や戦時体制論を含 めて考えなければならないだらう。 


\section{参考文献}

赤司政雄、1973、篤農の実体と意義、東京教育大学農学部紀要、 19

Anderson, B. 1991, Imagined Communities（Rev. ed）, Verso 青野正明、1991、朝鮮農村の『中堅人物】、朝鮮学報、141 坂野潤治、2008、日本憲政史、東京大学出版会 大日本農会、2001、大日本農会百二十年史、大日本農会

大日本聯合青年団、1932、第一回全国青年篤農家大会記録、 大日本聯合青年団

Fujitani,T, 1998, Splendid Monarchy、 University of Calfornia Press

フジタニ、T、1994、天皇のページェント、日本放送出版協 会

不破和彦、1978、日露戦後における農村振興と農民教化（II）、 東北大学教育学部研究年報、26

浜田陽太郎、1977、農本主義のはばたき、世界教育史研究会編、 農民教育史（世界教育史大系 35）、請談社

原武史、2001、可視化された帝国、みすず書房

原田信男、1993、歴史のなかの米と肉、平凡社

堀和生、1976、日本帝国主義の朝鮮に扔ける農業政策、日本 史研究、 171

井上晴丸、1972、日本資本主義の発展と農業抢よび農政（井 上晴丸著作選集 第 5 巻)、雄渾社

樺太庁拓殖部編、1923、樺太之産業、樺太庁

樺太庁内務部殖産課編、1925、樺太の農業、樺太庁内務部殖 産課

樺太庁農林部、1929a、篤農家講演集、樺太庁農林部

樺太庁農林部編、1929b、樺太農家の苦心談、樺太庁農林部

樺太庁殖民課、1933、農家経済調查、樺太朾殖民課

樺太拓殖調查委員会第一部委員、1933、樺太拓殖調查委員会 答申及説明書第一部（農業、牧畜業、植民）、北海道大学 図書館北方資料室所蔵

檴太庁殖産部、1934、樺太農法経営大体標準、北海学園図書 館所藏

樺太庁編、1936、樺太竹施政三十年史、樺太庁

木村誠編、1949、樺太人物鑑、全国樺太連盟情報部

駒达武、1993、異民族支配の〈教義〉、大江志乃夫ほか編、統 合と支配の論理（近代日本と植民地 4)、岩波畫店

小森陽一、2001、ポストコロニアル、岩波書店

工藤儀三郎、1940、弥栄開拓十年誌、満洲事情案内所

松田吉郎、2000、日本統治時代台湾の農業講習所について、 現代台湾研究、20

松本武祝、1998、植民地権力と朝鮮農民、社会評論社

松尾毅、1939、拓殖道場をのぞく、樺太、11（2）

三木理史、2003、農業移民に見る樺太と北海道、歴史地理学、 No. 212

三木理史、2006、国境の植民地・㮖太、塙書房
三木理史、2008、明治末期岩手県からの樺太出稼、蘭信三編、 日本帝国をめぐる人口移動の国際社会学、不二出版 森武痋、2005、戦間期の日本農村社会、日本経済評論社 モーリスニスズキ、T. (小林英里訳)、2002、植民地思想と移 民、搪大するモダニティ（岩波講座 近代日本の文化史 6)、岩波書店

内閣大礼記念編纂委員会編、1931、昭和大礼要録、内閣印刷 局

中山大将、2008、周縁におけるナショナル・アイデンテイティ の再生座と自然環境的差異、ソシオロジ、163

大門正克、1994、近代日本と農村社会、日本経済評諭社 岡田精司、1970、古代王権の祭祀と神話、塙書房 朴埈相、2003、天皇制国家形成と朝鮮植民地支配、人間の科 学新社

坂根嘉弘、1990、戦間期農地政策史研究、九州大学出版会 台北州農会、1937、青年篤農家講習録、台北州農会 高橋紘、1994、解説 創られた宮中祭祀、河井弥八著・高橋 紘ほか編、昭和初期の天皇と宮中 第 6 卷、岩波書店 高倉新一郎、1947、北海:道拓殖史、柏葉書院

竹野学、2000、人口問題と植民地、経済学研究、50（3）

竹野学、2001、植民地樺太農業の実体、社会経済史学、66 (5) 竹野学、2003、植民地開拓と「北海道の経験」一植民学にお ける「北大学派」一、北大百二十五年史 諭文・資料編、 北海道大学

竹野学、2005、樺太農業と植民学、札幌大学経済学部附属地 域経済研究所

竹野学、2008、㮖太、日本植民地研究会編、日本植民地研究 の現状と課題、アテネ社

富田晶子、1981a、農村振興運動下の中堅人物の養成、朝鮮史 研究会論文集、18

富田晶子、1981b、準戦時下朝鮮の農村振興運動、歴史評諭、 377

若林正丈、1992、一九二三年東宮台湾行啓と「内地延長主義」 大江志乃夫ほ加編、帝国統治の構造（近代日本と植民地 2)、岩波書店

大和和明、1982、1920 年代前半期の朝鮮農民運動、歷史学研究、 第 502 号

晏丸良夫、2001、近代天皇像の形成、岩波書客

張素玢、2001、台灣的日本農業移民（臺灣史研究諭叢 6)、國 史館

『樺太日日新聞』(1928 年 2 月 16 日号、同 10 月 7 日号、 1929 年 1 月 11 日号、 1941 年 10 月 21 日号)

『官報』（1928 年 11 月 22 日付 [号外]、同 23 日付、同 29 日付、 同 30 日付、同 12 月 10 日付、同 29 日付)

ГА А О, $\Phi .2$ и, О п .3, Д.12.

Г А С О, Ф.171, О п .1, Д.26.

(サハリン州国立公文書館 [略称：「 A C O ] 所藏一次史料に ついては資料番号を示した。) 